\title{
Fair Use Quotation Licenses: A Private Sector Solution To DMCA Takedown Abuse on YouTube
}

\author{
Timothy S. Chung*
}

\section{INTRODUCTION}

In 2019, YouTube logged two billion users a month and received over 500 hours of content uploads every minute. ${ }^{1}$ With over 4.5 billion people using the internet every day, it may come as no surprise that internet users congregate on the world's largest video-hosting platform to view, create, and share videos based on their common interests. ${ }^{2}$ The owners and creators of such content range from widely recognized figures, like musician Justin Bieber-whose channel has over 57 million subscribers - to more idiosyncratic individuals, like Steve1989MREInfo-who eats and reviews military rations for his fiercely loyal viewers. ${ }^{3}$ The vast and varied selection of content makes YouTube a particularly attractive hub of creativity and entertainment. Yet the same abundance of creative work also gives rise to countless opportunities for copyright infringement—an issue that YouTube has long grappled with. ${ }^{4}$

Although the rights given to copyright owners by the U.S. copyright statute can be exercised or transferred independently of each other, it is often the case that a

* J.D. Candidate, Columbia Law School, Class of 2021; B.A., Oberlin College, Class of 2016. My deepest thanks go to Professor Tim Wu for his guidance and oversight throughout this process. I also thank Anton Nemirovski, David A. Fischer, Warren Chu, Benjamin Feiner, Kate Garber, Alec Fisher, and the rest of the JLA staff for their tireless editorial efforts. Finally, I thank Emma, who has been an everlasting well of comfort and support to me.

1. See Todd Spangler, YouTube Now Has 2 Billion Monthly Users, Who Watch 250 Million Hours on TV Screens Daily, VARIETY (May 3, 2019), https:/variety.com/2019/digital/news/youtube-2-billionusers-tv-screen-watch-time-hours-1203204267; James Hale, More than 500 Hours of Content Are Now Being Uploaded To YouTube Every Minute, TUBEFILTER (May 7, 2019), https://perma.cc/ZW8A-QR9R. Roughly $73 \%$ of U.S. adults reported using the video-hosting platform. Andrew Perrin \& Monica Anderson, Share of U.S. Adults Using Social Media, Including Facebook, Is Mostly Unchanged Since 2018, PEW RSCH. CTR. (Apr. 10, 2019), https://perma.cc/7XQG-WDGX.

2. Internet Usage Statistics, INTERNET WORLD STATS, https://perma.cc/F87Z-L6E6 (last updated Mar. 3, 2020).

3. See Justin Bieber, YouTuBE, https://perma.cc/H3EC-GWZN (last visited Sept. 21, 2020); Steve1989MREInfo, YouTUBE, https://perma.cc/HWV2-B4RR (last visited Sept. 21, 2020).

4. See, e.g., Mason Sands, Why Copyright Will Be the Biggest Issue for YouTube in 2019 (Updated), FORBES (Dec. 30, 2018), https://perma.cc/LJ9P-DMNA.

(C) 2020 Chung. This is an open access article distributed under the terms of the Creative Commons Attribution License, which permits unrestricted use, distribution, and reproduction, provided the original author and source are credited. 
single work, like a YouTube video, implicates several rights at the same time. ${ }^{5}$ For example, several infringement suits could theoretically originate from a hypothetical viral video of a wedding attendee tripping over a child, where a CNN broadcast can be seen in the background and a local band's cover of a Pearl Jam song plays in the background. The potential for copyright infringement is more likely today than ever before, given the rapid changes in communications technology, including the rise of YouTube, over the past couple of decades. Whereas a few decades ago the average person's ability to violate copyright law was somewhat limited, "[t]oday every man, woman, corporation and child has the technological ability to copy and distribute, and therefore to potentially infringe copyright in ways both harmful and harmless." ${ }^{\prime}$ Copyright law, once the concern of a relative few right holders, is today a vast landscape that millions of individuals interact with on a daily basis. ${ }^{7}$

In 1998, Congress enacted the Digital Millennium Copyright Act ("DMCA") in an attempt to comprehensively equip U.S. copyright law to deal with the challenges of the new millennium. ${ }^{8}$ One benefit of the DMCA was the introduction of an online takedown mechanism, by which copyright owners could request the expeditious removal of infringing material online. ${ }^{9}$ Unfortunately, this DMCA takedown mechanism has also led to much abuse on internet platforms, including on YouTube. ${ }^{10}$ As this Note explains, such abuse often obviates other protections afforded to creators, because the mechanism by which a YouTube user can take down allegedly infringing content regularly bypasses any meaningful consideration of fair use.

The fair use doctrine recognizes that certain uses of copyrighted works should be shielded from liability for copyright infringement. ${ }^{11}$ However, aside from filing a counter notification, ${ }^{12}$ YouTube users who receive a takedown notice are effectively limited to asserting a fair use defense in court. This is largely because the fair use test requires the contemplation of four factors, none of which is singularly determinative of whether the work qualifies as a fair use. ${ }^{13}$ While the prospect of litigation might deter some right holders from initiating a DMCA takedown, the same prospect could deter content creators who appropriate copyrighted works from pursuing a fair use defense. As this Note argues, the resulting dynamic favors right holders, who have relatively little to lose by filing a DMCA takedown request. It also ensures that the fair use defense is virtually inaccessible to most content creators

5. The copyright statute is codified in Title 17 of the U.S. Code. The six exclusive rights, enumerated in $\S 106$, include the rights to (1) reproduce the work; (2) prepare derivative works based on the work; (3) distribute the work to the public; (4) perform the work publicly; (5) display the work publicly; and (6) transmit the work publicly (in the case of sound recordings). 17 U.S.C. § 106.

6. Tim Wu, Tolerated Use, 31 COLUM. J.L. \& ARTS 617, 618 (2008).

7. See John Tehranian, InFringement NATION: Copyright 2.0 AND You, at xv (2011).

8. Digital Millennium Copyright Act (DMCA), Pub. L. No. 105-304, 112 Stat. 2860 (1998).

9. See infra text accompanying notes 29-38.

10. See, e.g., Katharine Trendacosta, YouTube's New Lawsuit Shows Just how Far Copyright Trolls Have To Go Before They're Stopped, ELEC. FronTIER FounD. (Aug. 21, 2019), https://perma.cc/288PNUBE.

11. See 17 U.S.C. $§ 107$.

12. See infra Part I.A.

13. See 17 U.S.C. $§ 107$. 
on platforms like YouTube. Instead of working as a shield, DMCA takedowns have been used as a sword to remove fair use from the equation.

Part I of this Note covers the history of the fair use doctrine and its interplay with the DMCA, specifically within the context of video-hosting platforms like YouTube, ${ }^{14}$ and examines how recent case law developments concerning the DMCA have fostered an environment that is ripe for abuse. Part II then argues that most content creators on YouTube have little to no recourse if their fair use creations are flagged as infringing content by right holders who request DMCA takedowns. Specifically, YouTube's copyright policies and the excessive costs of litigation disincentivize users from fighting DMCA takedowns or pursuing legal actions to counteract bad faith behavior. As a consequence, the fair use defense is inaccessible to most YouTube content creators. Finally, Part III proposes the implementation of a quotation licensing scheme as one option to mitigate DMCA takedown abuse on YouTube. In recognizing the value of fair use for incentivizing creation, this scheme would contractually carve out a small exception to infringement, permitting limited appropriation of fellow users' content on YouTube.

\section{FAIR USE AND THE DMCA}

The rights endowed to authors under copyright law are not without limitation. In particular, copyright law has several "built-in First Amendment accommodations" to protect freedom of speech, including the idea/expression dichotomy and the fair use doctrine. ${ }^{15}$ The former, codified in 17 U.S.C. $§ 102$ (b), limits copyright protection to fixed expressions only; it will not cover an "idea, procedure, process, system, method of operation, concept, principle, or discovery." 16 For obvious reasons, placing restrictions on the use and exchange of ideas is difficult to reconcile with the expansive language of the First Amendment. The latter accommodation, codified in $\S 107$, permits limited use of copyrighted works for fair use purposes, including criticism, commentary, news reporting, education, or research. ${ }^{17}$ Much like the idea/expression dichotomy, courts have viewed fair use as a kind of First Amendment "safety valve" for the exclusive rights granted to copyright holders. ${ }^{18}$

The purposes of fair use, however, extend beyond simply protecting freedom of expression. It has also been deemed "necessary" by the Supreme Court to fulfill the constitutional purpose of furthering the "Progress of Science and useful Arts." 19 After all, true original creation is a rare phenomenon. In the words of Justice Story, "in literature, in science and in art ... few, if any, things, ... in an abstract sense, are strictly new and original throughout." ${ }^{20}$ Thus, carving out a space within copyright

14. The DMCA defines "service provider" as "a provider of online services or network access, or the operator of facilities therefor." Id. $\S 512(\mathrm{k})(1)(\mathrm{B})$.

15. Eldred v. Ashcroft, 537 U.S. 186, 219 (2003).

16. 17 U.S.C. $\$ 102$ (b).

17. Id. $\S 107$.

18. Universal City Studios, Inc. v. Reimerdes, 111 F. Supp. 2d 294, 322 (S.D.N.Y. 2000). cl. 8).

19. Campbell v. Acuff-Rose Music, Inc., 510 U.S. 569, 575 (1994) (quoting U.S. ConST. art. I, § 8,

20. Emerson v. Davies, 8 F. Cas. 615, 619 (C.C.D. Mass. 1845). 
for fair use furthers the goal of copyright to promote science and the arts by effectively enabling creation itself. ${ }^{21}$

Fair use is an affirmative defense to infringement, ${ }^{22}$ but it does not permit unreserved, blatant, haphazard reproduction of copyrighted works. In writing fair use into the Copyright Act in 1976, Congress intended to codify existing judicial doctrine, namely the multi-factor test described by Justice Story in Folsom $v$. Marsh $^{23}$ In determining whether the use of copyrighted expression is fair use, $\S 107$ mandates:

[T] he factors to be considered shall include-

(1) the purpose and character of the use, including whether such use is of a commercial nature or is for nonprofit educational purposes;

(2) the nature of the copyrighted work;

(3) the amount and substantiality of the portion used in relation to the copyrighted work as a whole; and

(4) the effect of the use upon the potential market for or value of the copyrighted work. ${ }^{24}$

As the language of the statute suggests, there is no single bright-line rule for the courts to apply. Unsurprisingly, this has generated a great deal of inconsistency and uncertainty about how to evaluate fair use. At one point, the Supreme Court suggested that any commercial use of a copyrighted work was presumptively unfair. ${ }^{25}$ However, several years later in Campbell v. Acuff-Rose Music, Inc., the Court declared that no factor was to be "treated in isolation," but that "[a]ll are to be explored, and the results weighed together, in light of the purposes of copyright.."26

Unfortunately, application of these factors has been far from uniform in the lower courts. By 1990, Judge Pierre Leval, recognizing the inconsistency with which courts applied the fair use test since its passage, opined that "courts ha[ve] failed to fashion a set of governing principles or values" for the fair use doctrine. ${ }^{27}$ More recently, examining empirical data of fair use opinions from 1978 to 2005, Professor Barton Beebe found, inter alia, that when it came to fair use analysis, many "lower courts repeatedly either deliberately ignored or were ignorant of basic, albeit dictic,

21. Campbell, 510 U.S. at 579.

22. Id. at 590 .

23. See H.R. ReP. No. 94-1476, at 66 (1976); Folsom v. Marsh, 9 F. Cas. 342, 348 (C.C.D. Mass. 1841) (instructing courts to "look to the nature and objects of the selections made, the quantity and value of the materials used, and the degree in which the use may prejudice the sale, or diminish the profits, or supersede the objects, of the original work").

24. 17 U.S.C. $\$ 107$.

25. Sony Corp. of Am. v. Universal City Studios, 464 U.S. 417, 451 (1984) (“"E]very commercial use of copyrighted material is presumptively an unfair exploitation of the monopoly privilege that belongs to the owner of the copyright ....").

26. 510 U.S. at 578

27. Pierre N. Leval, Toward a Fair Use Standard, 103 HARV. L. REV. 1105, 1105 (1990). 
Supreme Court precedent." 28 As the following section shows, this confusion and inconsistency only compound when fair use intersects with other copyright statutes, like the DMCA.

\section{A. The DMCA and the Safe Harbor Provisions}

In 1998, the United States signed the World Intellectual Property Organization ("WIPO") Copyright Treaty. The same year, Congress passed the DMCA, seeking to serve the pressing need to balance "the continued growth and development of electronic commerce" with the interests of right holders. ${ }^{29}$ The internet, after all, was a new technology that enabled the rapid copying and dissemination of works on a massive scale. The DMCA was meant to update U.S. copyright law and equip it to face the new challenges of the digital age.

The DMCA modified existing copyright law in two major ways. First, it gave copyright owners additional protections against the circumvention of digital rights management measures, in accordance with WIPO Articles 11 and 12. ${ }^{30}$ Second, it provided safe harbor protections for online service providers ("OSPs"), shielding them from liability for infringing content posted by users of their site. ${ }^{31}$ The four safe harbors created by $\S 512$ correspond to four types of online services: (1) direct internet services; (2) systems caching or temporary storage services; (3) hosting services for user-directed material (the category that includes YouTube); and (4) information location tools. ${ }^{32}$

These protections do not come without a price. In the case of host service providers like YouTube, safe harbor protections apply only if they adhere to certain statutory conditions outlined in $\S 512(\mathrm{c})(1)$, namely that the service provider lacks actual knowledge of infringement and "is not aware of facts or circumstances from which infringing activity is apparent," does not receive a financial benefit from the infringement, and "upon notification of claimed infringement ... responds expeditiously to remove, or disable access to, the material that is claimed to be infringing or to be the subject of infringing activity." 33

This section covers the third condition-requiring the expeditious removal of allegedly infringing material upon notice from the copyright owner in the form of a DMCA takedown request. It is this third condition that places YouTube's efforts to qualify for safe harbor protection in direct conflict with its users' ability to make fair use of others' work. ${ }^{34}$

The DMCA takedown process is user initiated, and begins when a copyright owner, observing an infringing use of their intellectual property, sends a written

28. Barton Beebe, An Empirical Study of U.S. Copyright Fair Use Opinions, 1978-2005, 156 U. PA. L. REV. 549, 556 (2008).

29. H.R. REP. NO. 105-551, pt. 2, at 23 (1998).

30. 17 U.S.C. $\S \S 1201-02$; WIPO Copyright Treaty, art. 11-12, Dec. 20, 1996, 2186 U.N.T.S. 121.

31. 17 U.S.C. $\$ 512(\mathrm{c})$.

32. Id. $\S 512(\mathrm{a})-(\mathrm{d})$.

33. Id. $\S 512(\mathrm{c})$. The service provider is also required to list an agent to receive notifications of claimed infringement to qualify for safe harbor protections. $I d$.

34. See infra Part II. 
notice to the hosting OSP, requesting that the host remove the allegedly infringing material. Once it receives this request, the OSP must then "expeditiously" take down the material or disable access to it (regardless of whether it is actually infringing), and inform the alleged infringer that it has done so. ${ }^{35}$ The alleged infringer then has the opportunity to issue a counter notification claiming that the original notice was issued in error. ${ }^{36}$ At this point, the OSP must "promptly" provide the copyright owner with a copy of the counter notification, and inform them that it will replace the removed content or cease disabling access to it in ten (or no more than fourteen) days. ${ }^{37}$ The copyright owner then has the opportunity to accept the counter notification or inform the OSP that they will file a legal action against the alleged infringer, during which time the OSP does not have to restore the allegedly infringing content. $^{38}$

\section{Good Faith, Misrepresentation, and the Rossi Standard}

A DMCA takedown process as described above, with no further provisions, would leave ample opportunities for abuse. For example, a user could select any piece of non-infringing content and initiate a DMCA takedown, effectively erasing another user's lawful content without consequence. Cognizant of this possibility, Congress wrote into the DMCA various safety valve provisions that were meant to guard against such abuse, including: (1) the requirement that a copyright owner alleging infringement submit any request for a DMCA takedown under a good faith belief that the use is actually infringing: ${ }^{39}$ and (2) creating a cause of action against persons who "knowingly materially misrepresent[]" whether the content was infringing or taken down by mistake. ${ }^{40}$ Though the threat of litigation might deter would-be miscreants from violating these provisions, two questions still needed answering: What constitutes good faith belief? And, should "knowingly materially misrepresents" be applied as a subjective or an objective standard?

Some clarification came in 2004 when the Ninth Circuit ruled, in Rossi v. Motion Picture Ass' $n$ of America, that both the good faith belief and the "knowing misrepresentation" standard called for a subjective application, which required a demonstration of actual knowledge of misrepresentation on the part of a putative right holder. ${ }^{41}$ The plaintiff in that case, Michael J. Rossi, owned and operated "www.internetmovies.com," a site that linked to other websites containing information about movies. ${ }^{42}$ Rossi described his membership-based site as "an internet news magazine providing information and resources about movies on the internet," but — perhaps fishing for the membership fees of credulous and inattentive users (a characterization that might well apply to the average internet user)-

35. 17 U.S.C. $\S 512(\mathrm{c})$.

36. $I d . \S 512(\mathrm{~g})(3)$.

37. Id. $\S 512(\mathrm{~g})(2)$.

38. $I d$.

39. Id. $\$ 512(\mathrm{c})(3)(\mathrm{A})(\mathrm{v})$.

40. Id. $\$ 512(\mathrm{f})$.

41. 391 F.3d 1000, 1007 (9th Cir. 2004).

42. Id. at $1001-02$. 
advertised bombastic declarations such as: "Join to download full length movies online now! new movies every month"; "Full Length Downloadable Movies"; and "NOW DOWNLOADABLE." 43 Much to Rossi's misfortune, the Motion Picture Association of America ("MPAA"), a trade association that represents several major film studios, discovered the site and promptly issued takedown notices to Rossi and his OSP in an effort to curb his seemingly infringing behavior. ${ }^{44}$ Rossi sued MPAA, asserting in one of his claims that the takedown notice constituted tortious interference with his contractual relationship with the OSP. ${ }^{45}$

The district court ruled in favor of MPAA. ${ }^{46}$ Although Rossi's claims were not based on $\S 512$ of the DMCA, the court determined that because the DMCA takedown requests comported with the good faith requirement in $\S 512(\mathrm{c})(3)$, MPAA did not act in a tortious manner. ${ }^{47}$ On appeal, Rossi contended that MPAA did not have enough information to form a good faith belief, and that the trade association should have been required to conduct a reasonable investigation into whether Rossi was actually infringing on their copyrights. ${ }^{48}$ In other words, Rossi viewed the good faith belief requirement as imposing an objective standard for assessing the reasonableness of a right holder's good faith when sending a DMCA takedown notice. The Ninth Circuit disagreed, concluding that case law and the statutory structure of the DMCA instead supported a subjective standard. ${ }^{49}$ In part, the court juxtaposed the good faith requirement with the "knowingly materially misrepresents" standard of $\S 512(\mathrm{f})$. It reasoned that because $\S 512(\mathrm{f})$ required "demonstration of some actual knowledge of misrepresentation on the part of the copyright owner," a subjective standard should also be applied to the good faith requirement. ${ }^{50}$

\section{Lenz and Fair Use Under the DMCA}

Case law surrounding the good faith requirement is further complicated when considered alongside the issue of fair use. After all, a copyright owner initiating a DMCA takedown must do so under the "good faith belief that use of the material in the manner complained of is not authorized by the copyright owner, its agent, or the law." ${ }^{51}$ So the question inevitably arises: Is a copyright owner compelled to consider whether allegedly infringing material qualifies as fair use before requesting a DMCA takedown? In Lenz v. Universal Music Corp., the Ninth Circuit considered this very question, and ultimately held that $\S 512$ of the DMCA "unambiguously contemplates fair use as a use authorized by the law," meaning a putative right holder must

43. Id. at 1002 .

44. $I d$.

45. Id.

46. Rossi v. Motion Picture Ass'n of Am., Inc., No. CIV. 02-00239BMK, 2003 WL 21511750 (D.

Haw. Apr. 29, 2003), aff'd, 391 F.3d 1000 (9th Cir. 2004).

47. Id. at $* 3$.

48. Rossi, 391 F.3d at 1003-04.

49. Id. at 1004 .

50. Id. at 1005 (emphasis added).

51. 17 U.S.C. $\$ 512(\mathrm{c})(3)(\mathrm{A})(\mathrm{v})$. 
consider fair use before submitting a DMCA takedown request. ${ }^{52}$ But crucially, the court did not go so far as to say that a right holder's analysis had to be correct.

In Lenz, young mother Stephanie Lenz filed suit against Universal Music Publishing, Inc. ("Universal") under § 512(f), alleging that Universal misrepresented that she infringed Universal's copyright in their takedown request, filed in response to a video she uploaded onto YouTube in 2007..$^{53}$ The video, "Let's Go Crazy' \#1," showed Lenz's toddler dancing to Prince's song "Let's Go Crazy," which played in the background. ${ }^{54}$ Universal—Prince's publishing administrator-found the video, concluded that the song was recognizable and was also the focus of the video, and submitted a DMCA takedown request. ${ }^{55}$ YouTube promptly removed the video and notified Lenz, who sent a counter notification in an attempt to get it reinstated. Although Lenz eventually got YouTube to reinstate the video, she chose to file suit against Universal in the Northern District of California, alleging misrepresentation under $\S 512(\mathrm{f}) .^{56}$

The district court considered whether the good faith requirement compelled a copyright owner to conduct a fair use analysis before concluding that infringement had occurred. ${ }^{57}$ The court ruled in the affirmative, holding that a copyright owner must "evaluate whether the material makes fair use of the copyright." 58 However, the court also held in a later proceeding that Universal was not necessarily liable for misrepresentation under $\S 512(\mathrm{f})$ for merely failing to consider fair use, explaining that since Universal's actions had to be considered under the subjective Rossi standard of good faith, Lenz was thus required to demonstrate that Universal had "some actual knowledge that its Takedown Notice contained a material misrepresentation." 59

The Ninth Circuit affirmed the district court's decision regarding the scope of the good faith requirement, declaring that copyright owners had a "duty to consider-in good faith and prior to sending a takedown notice-whether allegedly infringing material constitutes fair use." ${ }^{60}$ However, the subjective standard means that a prenotice fair use analysis does not have to be correct. Although the Ninth Circuit warned that merely paying lip service to fair use could still leave a right holder liable for misrepresentation, ${ }^{61}$ some worry that the court's decision may prove difficult to enforce because users like Lenz are left with the evidentiary burden of proving bad

52. 815 F.3d 1145, 1151 (9th Cir. 2016).

53. Id. at 1148 .

54. Stephanie Lenz, "Let's Go Crazy" \#1, YouTuBE (Feb. 7, 2007), https://perma.cc/4B2M-253Z.

55. Lenz, 815 F.3d at 1149 .

56. Id. at $1149-50$.

57. Lenz v. Universal Music Corp., 572 F. Supp. 2d 1150 (N.D. Cal. 2008).

58. Id. at 1154 .

59. Lenz v. Universal Music Corp., No. 5:07-CV-03783-JF, 2013 WL 271673, at *6 (N.D. Cal. Jan. 24, 2013).

60. Lenz, 815 F.3d at 1157.

61. Id. at 1154 . 
faith on the part of the right holders. ${ }^{62}$ This is even more troublesome because application of the fair use doctrine itself is in a state of confusion and disarray. ${ }^{63} \mathrm{~A}$ putative right holder could subjectively believe-based on their own flawed analysis - that an allegedly infringing work did not constitute fair use. Such an analysis, though wrong, easily could have been conducted in good faith, and a defendant would be hard-pressed to prove otherwise. As the next Part will show, this allocation of the evidentiary burden, compounded by doctrinal ambiguity, has led to a dynamic in which right holders are not sufficiently disincentivized from initiating bad faith DMCA takedowns on content that would likely qualify as fair use.

This is not to say that fair use was absent from legislative intent during the drafting of the DMCA. Indeed, fair use was addressed in the House Report, which opined that "[a]s more and more industries migrate to electronic commerce, fair use becomes critical to promoting a robust electronic marketplace." 64 But despite the Ninth Circuit's decision in Lenz, it is doubtful whether courts in other circuits will elect to follow the ruling, given that the DMCA does not explicitly address fair use in $\S 512(\mathrm{c})$ or $\S 512(\mathrm{f}){ }^{65}$

The problems discussed above come into sharp focus in the context of heavily trafficked creative platforms like YouTube. In these environments, when alleged infringers bear the burdens of proving both bad faith and fair use, right holders can initiate DMCA takedowns with virtual impunity, even if the content likely qualifies as fair use.

\section{WHY YOUTUBE AND THE DMCA CREATE A FAIR USE CONUNDRUM}

In order to obtain a definitive ruling on whether the use of a work is fair use, creators facing a DMCA takedown notice must file suit in federal court, because the fair use test requires the contemplation of four factors, none of which is singularly determinative of whether the work qualifies as fair use. ${ }^{66}$ Although the prospect of

62. See Joel D. Matteson, Unfair Misuse: How Section 512 of the DMCA Allows Abuse of the Copyright Fair Use Doctrine and how To Fix It, 35 SANTA ClaRA High TECH. L.J. 1, 10 (2018) ("While the Lenz decision sounds encouraging, the decision is difficult to enforce because the user must somehow prove bad faith or willful blindness on the part of the DMCA complainant."). See also Recent Case, Lenz v. Universal Music Corp., No. 13-16106, 2016 WL 1056082 (9th Cir. Mar. 17, 2016), 129 HARV. L. Rev. 2289, 2293 (2016) (“'T]he Ninth Circuit's interpretation of the actual knowledge standard means that, to prove 'knowing' misrepresentation, a plaintiff must show (as long as the copyright holder claims to have evaluated fair use) that the copyright holder did not actually believe the takedown target to be outside fair use. Having to show such nonexistence of a claimed belief presents a prohibitively high evidentiary burden, as one would have to produce evidence of another's state of mind. This high evidentiary burden, along with the court's refusal to explicitly establish what kinds of fair use analyses are necessary, creates an unsavory incentive for copyright holders to avoid learning conclusively whether a use constitutes fair use." (emphasis added)).

63. See supra notes $25-28$ and accompanying text.

64. H.R. REP. NO. 105-551, pt. 2, at 26 (1998).

65. Matteson, supra note 62, at 11-12. As of this writing, no other circuits have chosen to adopt the Lenz standard.

66. 17 U.S.C $§ 107$. 
such litigation might deter some right holders from even submitting a DMCA takedown request, the same prospect could also deter content creators from fully asserting a fair use defense. While a user can issue a counter notification in response to a DMCA takedown notice they believe was filed in error, the putative right holder who initiated the takedown decides what happens next. If the putative right holder does nothing in response to the counter notification, YouTube restores access to that content. However, the putative right holder may also file an infringement suit in court, in which case the content is kept down during the course of the litigation. Even if the putative right holder originally filed the DMCA takedown request in bad faith and the allegedly infringing user proactively brings a $\S 512(\mathrm{f})$ misrepresentation claim against the right holder because of that bad faith, the evidentiary hurdle that the infringing user would have to clear in order to prove subjective bad faith makes it difficult for users to triumph in court on those claims. ${ }^{67}$ This dynamic greatly favors putative right holders, who have relatively little to lose by alleging infringement through a DMCA takedown request. While allegedly infringing users can also choose to go to court to seek a declaratory judgment that their work is fair use, few users choose to take this action. Most flagged users on YouTube unfortunately cannot pursue litigation due to the time and costs involved, and therefore cannot respond to a DMCA takedown in any meaningful way if fear or ignorance prevent them from filing a counter notification.

\section{A. YouTube's COPYRIGHT ENFORCEMENT TOOLS AND THE DMCA}

Viacom v. YouTube, Inc. famously affirmed that YouTube was an OSP protected under the safe harbor provisions of the DMCA. ${ }^{68}$ Yet, ever conscientious of losing its safe harbor status, YouTube has since implemented a robust copyright enforcement regime that has invited both praise and controversy. The rights management tools most relevant to this discussion are YouTube's copyright takedown notice mechanism and its related copyright strike system, but some description of YouTube's Content ID system is warranted as well. ${ }^{69}$

The significance of YouTube's role as the world's largest video-hosting platform can hardly be overstated. In the United States, YouTube has a roughly $70 \%$ market share among online video platforms, and remains by far the dominant video platform for small and large creators alike. ${ }^{70}$ Therefore, while YouTube's copyright tools and policies are specific to its platform, they have the capacity to affect millions, if not billions, of internet users.

67. See supra Part I.A.1.

68. See generally Viacom Int'l Inc. v. YouTube, Inc., 676 F.3d 19 (2d Cir. 2012).

69. YouTube offers other rights management tools for its users, including its Copyright Match Tool, and Content Verification Program. See Copyright Management Tools, YouTuBE HelP, https://perma.cc/YD7B-HBU3 (last visited Sept. 20, 2020).

70. Online Video Platforms, DATANYZE, https://perma.cc/72WX-AZEP (last visited Sept. 20, 2020). 


\section{Content ID}

A video on YouTube can be flagged for infringement in one of several ways. First, the platform provides certain users access to its Content ID service, which the company describes as an "automated, scalable system that enables copyright owners to identify YouTube videos."71 To take advantage of the system, content owners who meet certain criteria must first submit an application to YouTube, including proof of exclusive rights to the content they seek to protect and a demonstrated need to use Content ID. ${ }^{72}$ Qualifying owners then upload their content onto YouTube, which scans its entire platform and automatically flags any videos that match the uploaded content. ${ }^{73}$ For each matching video, a qualifying owner can elect to (1) block the entire video from being viewed; (2) monetize the video by collecting its ad revenue; or (3) track its viewership statistics. ${ }^{74}$

To be sure, the automated Content ID system is a powerful and effective tool for enforcing copyrights on a large scale. With hundreds of hours of content from millions of users uploaded onto YouTube every minute, copyright owners who wished to enforce their rights prior to Content ID were faced with the onerous task of combing the entirety of YouTube's database for potentially infringing content. ${ }^{75}$ Further, right holders could not necessarily pin any liability on YouTube, since it often has no knowledge of infringing behavior and therefore qualifies for the DMCA's safe harbor protections. ${ }^{76}$ Instead, Content ID provides right holders a near-comprehensive tool that can efficiently monitor and protect their copyrighted works from sustained infringement. As such, YouTube has promoted its Content ID system as an "industry-leading rights management system," and claimed in 2016 that the system encompassed $98 \%$ of all copyright management on the platform, while paying out over $\$ 2$ billion to right holders. ${ }^{77}$

Unfortunately, since its conception Content ID has come under fire, particularly for its inability to distinguish between infringing and non-infringing uses. ${ }^{78}$ While the copyright issues specific to Content ID are beyond the scope of this Note, they

71. Using Content ID, YouTuBE HeLP, https://perma.cc/EH84-FBHJ (last visited Sept. 20, 2020).

72. Qualify for Content ID, YouTUBE HeLP, https://perma.cc/BT79-CS2C (last visited Sept. 20, 2020).

73. How Content ID Works, YouTUBE HeLP, https://perma.cc/BV2X-B8RG (last visited Sept. 20, 2020).

74. Id

75. See supra note 1 and accompanying text.

76. See generally Viacom Int'1 Inc. v. YouTube, Inc., 676 F.3d 19 (2d Cir. 2012). However, the court in Viacom also held that being willfully blind to infringing behavior could also result in the loss of safe harbor protection. ("Accordingly, we hold that the willful blindness doctrine may be applied, in appropriate circumstances, to demonstrate knowledge or awareness of specific instances of infringement under the DMCA.") Id at 35.

77. Katherine Oyama, Continuing To Create Value While Fighting Piracy: An Update, Google: KEYWORD (July 13, 2016), https://perma.cc/H3EU-G2UW.

78. For example, Content ID has demonstrated a proclivity to flag content whose creator and copyright owner are the same person. See, e.g., Tom Gerken, YouTuber in Row Over Copyright Infringement of His Own Song, BBC (July 5, 2018), https://perma.cc/X828-XF9J; Amul Kalia, Congrats on the 10-Year Anniversary YouTube, Now Please Fix Content ID, ElEC. Frontier Found. (May 1, 2015), https://perma.cc/9FG4-7CH7. 
do implicate some of the same concerns related to fair use. YouTube readily admits that its automated Content ID system cannot distinguish fair use, and encourages users to "defend [their] position through the Content ID dispute process." ${ }^{\text {" Content }}$ ID claims that are disputed and marked as potentially invalid are placed in a queue for manual review by the original content owner. ${ }^{80}$ While a user whose content is flagged by Content ID can successfully dispute the claim in cases in which the user is actually the copyright owner of an erroneously flagged video, the same process might not be effective for users who believe their content qualifies as fair use. ${ }^{81} \mathrm{~A}$ video that borrows content from another video often appears on the surface to be infringing, and an original content owner unfamiliar with the abstruse fair use doctrine might be unwilling to release their claim.

YouTube acknowledges this possibility and simply advises users that they may need to "carry that dispute through the appeal and DMCA counter notification process." 82 However, as described in the following section, the YouTube DMCA takedown mechanism is itself rife with opportunities for abuse and is similarly unable to account for fair use.

\section{YouTube's Copyright Takedown Notice and Copyright Strike System}

Unlike Content ID, which is an internal copyright enforcement system created by YouTube, the copyright takedown notice tool is YouTube's formal takedown mechanism created in direct compliance with $\S 512(\mathrm{c})$ of the DMCA ${ }^{83}$ Furthermore, while Content ID is available only to a select few creators with large libraries of content, the takedown tool is available to any user on the platform. ${ }^{84}$ A right holder, upon discovering an infringing use of their content, can complete and submit a copyright infringement notification webform to promptly remove or disable access to the infringing work. ${ }^{85}$ In compliance with the process described in the DMCA, once YouTube receives the notice, it removes or disables access to the video and informs the infringing user that it has done so. ${ }^{86}$ In order to discourage repeat infringing behavior, YouTube couples its takedowns with a "copyright strike" system. ${ }^{87} \mathrm{~A}$ user who is subject to a DMCA takedown will also receive a strike, and

79. Frequently Asked Questions About Fair Use, YOUTUBE HeLP, https://perma.cc/FP73-T8FE (last visited Sept. 20, 2020).

80. Dispute a Content ID Claim, YouTuBE HeLP, https://perma.cc/TX4Y-REQW (last visited Sept. 20, 2020)

81. Katharine Trendacosta, A Tool that Removes Copyrighted Works Is Not a Substitute for Fair Use, ElEC. FRONTIER FOUND. (Jan. 20, 2020), https://perma.cc/8ZX9-B5Z9.

82. Frequently Asked Questions About Fair Use, supra note 79.

83. See The Difference Between Copyright Takedowns and Content ID Claims, YouTuBE HeLP, https://perma.cc/H7NY-R28U (last visited Sept. 25, 2020).

84. See How Content ID Works, supra note 73.

85. Submit a Copyright Takedown Notice, YouTuBE HeLP, https://perma.cc/FB5D-SA4B (last visited Sept. 25, 2020).

86. Id.

87. See Copyright Strike Basics, YouTuBE HeLP, https://perma.cc/LB7Z-UBT4 (last visited Sept. 25,2020 ). Section 512(i) of the DMCA also requires OSPs who desire safe harbor protections to adopt a 
must complete a session in YouTube's mandatory "Copyright School," which includes a series of didactic but humorous video lessons on copyright, fair use, and DMCA takedowns. ${ }^{88}$ A user can contest the takedown and appeal the strike by submitting a counter notification, but if their appeal fails, the strike remains on their account and the user will be subject to penalties. ${ }^{89}$ Penalties for receiving strikes include losing the ability to monetize content and restricted access to live streaming; YouTube's penalty for receiving three strikes includes the removal of all of a user's uploaded videos and account termination. ${ }^{90}$ While the system indubitably has the potential to disincentivize infringing behavior and dissuade repeat infringement, these tools are also subject to abuse.

The phenomenon of DMCA takedown abuse is nothing new, and critics have been far from timid in pointing out the deficiencies in the system. ${ }^{91}$ The Electronic Frontier Foundation ("EFF") rather amusingly maintains a "Takedown Hall of Shame," which collects what it considers the "worst of the worst" copyright and trademark complaints that "threaten[] all kinds of creative expression"; many of its inductees have been "honored" for DMCA takedown abuse. ${ }^{92}$ However, DMCA takedown abuse on YouTube is much more likely to threaten creative expression than similar abuse on other platforms because of the amplified injuries that issue from pairing DMCA takedowns with YouTube's copyright strike system, and because uninformed users are often loathe to submit counter notifications for fear of legal repercussions.

A copyright strike carries serious consequences; as explained above, multiple strikes will result in the loss of one's account and removal of all videos on a channel. ${ }^{93}$ For a YouTuber who derives their livelihood from creating and sharing videos on the platform, the suspension or termination of their account would be a significant loss. ${ }^{94}$ In light of this, the copyright strike system has become, for some,

policy that "provides for the termination in appropriate circumstances of subscribers and account holders of the service provider's system or network who are repeat infringers." 17 U.S.C. § 512(i)(1)(A).

88. Copyright Strike Basics, supra note 87.

89. Id.

90. Id.

91. See, e.g., Jennifer M. Urban \& Laura Quilter, Efficient Process or "Chilling Effects"? Takedown Notices Under Section 512 of the Digital Millennium Copyright Act, 22 SANTA ClARA HigH TECH. L.J. 621, 681 (2006) (observing a "high incidence of questionable uses" of the DMCA takedown mechanism, but also suggesting that many who file takedown requests "simply seem not to understand the parameters of copyright law"); Lydia Pallas Loren, Deterring Abuse of the Copyright Takedown Regime by Taking Misrepresentation Claims Seriously, 46 WAKE FOREST L. REV. 745 (2011). For an empirical analysis of recent DMCA takedown notices, see Daniel Seng, The State of the Discordant Union: An Empirical Analysis of DMCA Takedown Notices, 18 VA. J.L. \& TECH. 369 (2014).

92. Takedown Hall of Shame, ELEC. FRONTIER FOUND., https://perma.cc/2B7W-94GL (last visited Sept. 25, 2020).

93. See Copyright Strike Basics, supra note 87.

94. Many full-time YouTubers already find it hard enough to make ends meet. See Chris StokelWalker, "Success" on YouTube Still Means a Life of Poverty, BloOMBerg (Feb. 27, 2018), https://perma.cc/HY63-UBRS. 
a tool for blackmail and extortion, as well as for doxxing efforts. ${ }^{95}$ More relevant to this discussion, though, is how the fear of receiving a DMCA takedown notice-and the accompanying copyright strike - stifles creativity, and how the high cost of potential litigation disincentivizes YouTube creators from disputing takedowns issued against content that may qualify as fair use.

This problematic dynamic was on vivid display when YouTubers Veronica Wang and SAS-ASMR submitted DMCA takedown requests against a parody channel called Shookbang. The key questions at the center of the incident were whether the channel's parodic compilations of "mukbang" videos constituted fair use and whether the owners of the original content were in the right, legally or morally, to request the videos' removal. ${ }^{96}$

Wang and SAS-ASMR are both popular creators of ASMR mukbang videos. ${ }^{97}$ Sometime in early December, comedy channel Shookbang created a heavily edited, self-described parodic compilation video based on some of Wang's ASMR content. Taking offense to the parodies, Wang filed two DMCA takedown requests against Shookbang's videos. ${ }^{98}$ Shortly thereafter, SAS-ASMR filed a DMCA takedown request against another one of Shookbang's videos, bringing the tally up to three YouTube copyright strikes for Shookbang. ${ }^{99}$ Shookbang chose not to appeal the claims by filing a counter notification, for fear of exposing personal information and potentially incurring high litigation costs, and the account was subsequently shut down. ${ }^{100}$ Although both Wang and SAS-ASMR eventually retracted their takedown requests after receiving much pushback from fans and pressure from the rest of the YouTube community - many of whom believed that Shookbang could raise a fair

95. Doxxing refers to the unscrupulous practice of collecting someone's personal information and then publicly releasing it online. See Beth Brindle, What Is Doxxing?, HowStuFFWorKS (Feb. 23, 2015), https://perma.cc/H75W-XDF8. See also Shoshana Wodinsky, YouTube's Copyright Strikes Have Become a Tool for Extortion, VERGE (Feb. 11, 2019), https://www.theverge.com/2019/2/11/18220032/youtubecopystrike-blackmail-three-strikes-copyright-violation; The PewDiePie Archive, "Can We Copystrike PewDiePie?" // Twitch Drama \#1 (Deleted PewDiePie Video), YouTuBe (July 11, 2020), https://perma.cc/FU9H-HNG5 (discussing how Twitch streamer and YouTuber Alinity threatened to "copystrike" PewDiePie's video for using sexually derogatory language against her).

96. See Anjelika Oles, YouTubers STEALING MONEY?! (False Copyright Claims on PewDiePie, Shookbang, and Cody Ko), YouTuBE (Dec. 30, 2018), https://perma.cc/MM2K-3F7T.

97. Autonomous sensory meridian response (ASMR) video creators produce content that often triggers a pleasant, tingling sensation in its viewers. See German Lopez, ASMR, Explained: Why Millions of People Are Watching YouTube Videos of Someone Whispering, Vox (May 25, 2018), https://www.vox.com/2015/7/15/8965393/asmr-video-youtube-autonomous-sensory-meridian-response. Mukbang (from the Romanization of the Korean word, 먹 방, translated as "eating broadcast") is a recently popular genre of videos in which hosts eat in front of a camera, often while speaking to live viewers on content-hosting platforms like YouTube, Twitch, or Korea's Afreeca TV. See generally Jasmin Barmore, Bethany Gaskin Is the Queen of Eating Shellfish Online, N.Y. TIMES (June 11, 2019), https://perma.cc/V9MH-KMFD.

98. Spill, Mukbang Drama with Veronica Wang and SAS-ASMR Forces Shookbang To Reveal Identity, YouTUBE (Jan. 21, 2019), https://perma.cc/9BT8-Z2F5.

99. Id.

100. $I d$. 
use defense ${ }^{101}$ — they both reiterated that they nonetheless believed that Shookbang's videos were not protected by fair use. ${ }^{102}$

Therein lies the problem: While fair use requires consideration of the four-factor test, users who submit DMCA takedown requests could arrive, through subjective analysis of the factors, at different conclusions. Remember that the question of whether a work qualifies as fair use is difficult to answer, even for the various courts across the country. ${ }^{103}$ Consider also that the average user may not be fully acquainted with the latest case law developments in fair use doctrine or even how a fair use defense is properly raised. ${ }^{104}$ The ability to file counter notifications in response to a takedown does not provide a full remedy either. Bolder and more sophisticated parties may successfully issue counter notifications that resolve any erroneouslyissued or bad faith takedowns. But others, who have a tenuous understanding of fair use and a healthy fear of legal confrontation, can be easily cowed into accepting a takedown. Additionally, most YouTube creators cannot rely on recurring waves of popular outrage for protection or solutions. Furthermore, the Ninth Circuit's ruling in Lenz concerning fair use merely requires that users who request a DMCA takedown must consider fair use, not that their analysis must be correct. ${ }^{105}$ In this case, it would appear that both Wang and SAS-ASMR did just that, as they both claimed to have arrived at the conclusion that Shookbang's parodies were not fair use. $^{106}$

Had Shookbang decided to proactively pursue litigation, Shookbang could have brought a claim against Wang and SAS-ASMR alleging they materially misrepresented their knowledge of infringement concerning Shookbang's videos and were therefore liable under $\S 512$ (f). In doing so, Shookbang might have argued that Wang and SAS-ASMR did not properly consider fair use, opting instead to allege infringement while only paying lip service to fair use. But as Lenz demonstrated, a party alleging misrepresentation and bad faith carries the initial burden of demonstrating "some actual knowledge that its Takedown Notice contained a material misrepresentation." 107 It would have been up to Shookbang to prove that Wang and SAS-ASMR did not adequately consider fair use and that they had issued the takedown in bad faith. But how does one go about this? Wang and SAS-ASMR certainly had grounds for believing that the videos did not constitute fair use given

101. See Nikocado Avocado 2, Fire Noodles • Discussing Veronica Wang (Hot Tea) $\bullet$ MUKBANG, YouTuBE (Dec. 19, 2018), https://perma.cc/XF6U-5SGC. See also PewDiePie, STOP DOING THIS!Copyright Striking Criticism etc, YOUTUBE (Jan. 11, 2019), https://perma.cc/XR7Q-6UCM.

102. Spill, supra note 98.

103. See supra notes $25-28$ and accompanying text.

104. See, e.g., YouTube user PaymoneyWubby's claim that "[he was] allowed to take clips and review them and critique them-I thought that was okay." PaymoneyWubby, YouTube STILL Does Not Care About Fair Use, YouTUBE (Aug. 29, 2018), https://perma.cc/RHQ9-RUBP. Contrary to PaymoneyWubby's assertion, fair use does not necessarily "allow" the use of copyrighted material, but rather can exempt an infringing use, if successfully argued in court.

105. See Lenz v. Universal Music Corp., 815 F.3d 1145, 1154 (9th Cir. 2016) ("We therefore judge Universal's actions by the subjective beliefs it formed about the video.").

106. Spill, supra note 98 .

107. Lenz v. Universal Music Corp., No. 5:07-CV-03783-JF, 2013 WL 271673, at*6 (N.D. Cal. Jan. 24, 2013). 
that a significant portion of Shookbang's videos were direct reproductions of Wang's and SAS-ASMR's videos. This would have presented a significant evidentiary hurdle for Shookbang had the issue been pursued in court. For those who have the resources, litigation might be an effective tool to dissuade bad faith takedowns and properly assert a fair use defense. But for others like Shookbang, whose small channels generate little revenue, the costs are simply insurmountable. ${ }^{108}$

\section{B. Bad Faith And High Litigation Costs: The Difficulties of ASSERTING FAIR USE}

According to the 2019 Report of the Economic Survey conducted by the American Intellectual Property Law Association, the median cost of litigating a copyright infringement case through trial ranged from $\$ 550,000$ to $\$ 6.5$ million depending on the value of the copyrighted assets. ${ }^{109}$ For most YouTubers, these are simply not dollars that they are willing or able to spend to assert a fair use defense or allege misrepresentation under the DMCA. ${ }^{110}$ Even massively popular YouTubers like h3h3Productions, a husband and wife YouTube duo with over 6.6 million subscribers, claimed they needed to start a fundraiser to cover their litigation costs for an infringement suit initiated by content creator Matt Hosseinzadeh in 2017. ${ }^{111}$ While the case resulted in a victory for $\mathrm{h} 3 \mathrm{~h} 3$, who successfully raised a fair use defense for the videos in question, such cases are rare for small channels like Shookbang who cannot make it to litigation in the first place. ${ }^{112}$

Though parties that misrepresent their DMCA claims may be subject to penalties and damages, extreme bad faith behavior is only curbed in this way if the parties on the receiving end of a DMCA takedown are ultimately willing and able to pursue misrepresentation claims or declaratory judgments that an infringing use is fair use. Unfortunately, most YouTubers do not seem to have sufficient resources or are so fearful of overbearing costs that litigation simply is not an option. ${ }^{13}$ As was the case with Shookbang, this disparity in postural power between YouTube users who issue DMCA takedown requests and those on the receiving end who face the possibility of losing their channels creates a dynamic that fails to dissuade right holders from

108. At the time the DMCA takedowns were issued, Shookbang had roughly 44,000 subscribers. See Spill, supra note 98.

109. Am. Intell. Prop. L. Ass'N, Report of THE ECONOMiC Survey 2019, at 54 (2019).

110. A YouTube channel would need about 700,000 subscribers and 224 million total video views to reach approximately $\$ 480,000$ in estimated earnings. How Much Do YouTubers Make? A YouTuber's Pocket Guide [Calculator], INFLUENCER MKTG. HuB, https://perma.cc/GHD5-6HRJ (last visited Mar. 20, 2020).

111. See Hosseinzadeh v. Klein, 276 F. Supp. 3d 34 (S.D.N.Y. 2017); Help for H3H3, GoFundME, https://perma.cc/NR8N-7LLY (last visited Mar. 20, 2020).

112. See, e.g., Hooverr, another YouTube creator facing a DMCA takedown notice, bemoaned the fact that the filer, Ray William Johnson, could opt to reject Hooverr's appeal, automatically leaving him with a copyright strike. Speaking of litigation, Hooverr remarked, "I don't want to go through that, I'm a f-g small channel; I'm not making a lot of money." (As of October 2020, Hooverr had 155,000 subscribers.) Hooverr, Ray William Johnson Took Down My Video, YouTUBE (Jan. 2, 2019), https://perma.cc/YN2E-D2UP.

113. Id. 
issuing ill-conceived requests. In other words, right holders who issue takedowns in bad faith receive a massive windfall, in that they can reliably depend on the fact that the costs of litigation and fear of YouTube copyright strikes will prevent many parties on the receiving end from retaliating either in court or through YouTube's appeal process. After all, the ramifications of a takedown on YouTube are not limited to the removal of a single video but may include threatening a user's entire business and livelihood. These factors ultimately work together to produce a profound chilling effect on creativity and fair use among YouTube creators.

\section{THE LICENSING SOLUTION AND OTHER POTENTIAL SOLUTIONS}

One potential solution to DMCA takedown abuse would be the implementation of a platform-wide compulsory licensing scheme that permits limited amounts of appropriation by users within the YouTube ecosystem. Such a scheme would have an immediate remedial effect on DMCA takedown abuse on YouTube and would further incentivize creativity, generating more value by and for its users. Other potential solutions may come from the pressures of market forces or legislation in the form of the pending CASE Act.

\section{A. Fair Use Quotation Licensing}

YouTube could revamp its sitewide enforcement regime by introducing a compulsory licensing scheme - to which users opt in by simply accepting the Terms of Service - that would allow for limited quotation of its users' video content, with its limitations modeled on fair use norms. ${ }^{114}$ As with its Content ID system, this would be a private, internal enforcement scheme, but would embody fair use principles by creating a kind of content commons that users could draw from to create their own videos while receiving compensation from those who appropriate their content in turn. In effect, this proposed licensing scheme would greatly mitigate DMCA takedown abuse on YouTube and give users a way to make limited use of copyrighted works to create more original content.

The scheme would begin with the Terms of Service, through which YouTube would require all users to allow limited appropriation of their content by other users in the community. Requiring all users to participate in the scheme would eliminate the additional costs incurred when individual users have to license directly with other users, or otherwise hope that fair use or some other mechanism shields them from infringement liability. Furthermore, YouTube would be able to enforce their scheme by means of the Terms of Service. Any user found to violate the terms of their agreement, including the terms of the compulsory license, could be duly penalized according to YouTube's stipulations, which might potentially include account suspension or temporary loss of the ability to monetize videos.

114. Under this scheme, copyrighted nondramatic musical works would necessarily be exempt from this licensing scheme as creators can already easily obtain various compulsory or mechanical licenses for their usage. 
Of course, in order to keep users from immediately abandoning ship, YouTube would have to couple this appropriation allowance with adequate compensation for its users. That is, YouTube would have to limit the amount of content a single user could take from a single video owned by another user to a predetermined percentage. ${ }^{115}$ To disincentivize users from simply reposting unaltered clips that fall within the allowable quoted percentage of the original video but may in fact compete with the original, YouTube could also require users to add original content, such as commentary, to the appropriated content. Under this scheme, YouTube would dole out revenue in proportion to the amount of content that is borrowed. Compensation could be scaled according to the percentage of content taken and paid on the basis of how many individual views a video gets. In order to avoid upfront costs, compensation for right holders whose content is incorporated into new a YouTube video could come out of any ad revenue that the new video generates, as opposed to any upfront licensing fees. In addition to compensation, users could also be required to provide attribution for the source material, thereby furthering a culture of shared use.

The scheme proposed herein would largely curb DMCA takedown abuse by: (1) carving out a zone of non-infringement; and (2) giving users sufficient notice of how much content they can appropriate without infringing. This would effectively eliminate the need for fair use analysis, provided creators' content use remains within the zone of non-infringement. Content used within the limitations of the licensing scheme would not constitute infringement, and right holders who flag content that falls within its parameters would be violating the Terms of Service, thereby opening themselves up to YouTube's penalties. These rules could also be integrated into the current Content ID system. Content ID could leave intact videos that conform to the rules of the licensing scheme, although users who posted videos prior to the implementation of this scheme would have to agree to the changes in the new user agreement. ${ }^{116}$ Furthermore, current technologies like the Content ID algorithm could be utilized to monitor whether users are properly adhering to the licensing scheme's terms. DMCA takedowns issued on rule-conforming content could be sent for manual review by a YouTube employee, or simply retracted as they would not constitute infringement under the license agreement.

115. One method YouTube could utilize to determine the exact percentage amount that best represents proper fair use is by conducting an empirical analysis of recent fair use decisions or creating user surveys. The number would have to be adjusted accordingly to account for consumers' preferences for small round numbers. See generally Michael Lynn, Sean Masaki Flynn \& Chelsea Helion, Do Consumers Prefer Round Prices? Evidence from Pay-What-You-Want Decisions and Self-Pumped Gasoline Purchases, 36 J. ECON. PsYCHOL. 96 (2013). Admittedly, situations may arise in which users appropriate small yet integral sections of a copyrighted work, akin to the heart of the work (for example, an iconic moment of a short film or a popular segment of a music video). YouTube would need to consider how to mitigate such situations as it comes up with an appropriate percentage for its fair use quotation licensing scheme.

116. Alternatively, videos that were created prior to implementation could be exempt from the new arrangement. Confusion arising out of instances when a user mistakenly appropriates material from an exempt older video could be avoided simply by indicating, under the video's description, whether the video's right holder has agreed to the new fair use quotation scheme. 
One foreseeable objection to this proposal is that not all YouTube channels are monetized. If the scheme is set up such that licensing fees can only come from ad revenue, what about the users who do not qualify for monetization or do not seek to monetize in the first place? Unfortunately, under this proposal, such users would not be included in the licensing scheme and the status quo would have to suffice. ${ }^{117}$

An additional concern for YouTube, should they implement this scheme, might be the possibility that some big-name creators or right holders would not want smaller creators to appropriate their works, regardless of monetary compensation. ${ }^{118}$ Such users, as a consequence, may decide to switch from YouTube to another platform that has not implemented a similar fair use quotation licensing scheme. Although YouTube's position as the largest and most popular video-hosting platform may incentivize some users to stay, YouTube may have to implement additional services or policies so that it remains an attractive creative entertainment platform for users.

It is important to consider that any appropriation of content permissible under the licensing scheme would be very limited, and new works likely would not usurp or replace the original works, especially if YouTube requires its users to add original content to any videos they borrow. In this regard, right holders likely would not have to worry about losing views to competitors. By more effectively encouraging creativity on its platform, both new and current users may be incentivized to create more videos, which in turn would increase YouTube's user base and generate even more ad revenue for the platform in the long run. DMCA takedown abuse has been a major concern for many high-profile YouTubers, ${ }^{119}$ and providing a fix to this problem would help alleviate the rather embarrassing situation in which YouTube's most successful partners publicly lambast YouTube on its own platform for its inadequacies. ${ }^{120}$ This fix could also re-incentivize users who were on the cusp of leaving, to actually stay on the platform.

This proposal would not entirely supplant the DMCA takedown mechanism. Instead, the compulsory licensing scheme and DMCA takedown mechanism could work in conjunction to encourage licensed use and fair use while disincentivizing infringement. In circumstances where the content creator appropriates more than the system allows, right holders would still have recourse through the DMCA takedown mechanism. Content creators would effectively have a choice: either stay within the predefined confines of the licensing scheme or overstep its boundaries and risk a DMCA takedown and potential litigation. In circumstances where the content

117. Unfortunately, statistics on the number of YouTube channels eligible for monetization are not readily available, though it is likely that a significant number of users actually do meet YouTube's relatively low requirements: logging 4,000 public watch hours in the last twelve months and having 1,000 or more subscribers to their channel. See YouTube Partner Program Overview \& Eligibility, YOUTUBE HELP, https://perma.cc/29YS-8D7Q (last visited Sept. 25, 2020).

118. Right holders and creators, for example, might place great value in vindicating their perceived moral rights.

119. See, e.g., Tom Scott, YouTube's Copyright System Isn't Broken. The World's Is., YOUTUBE (Mar. 23, 2020), https://perma.cc/R68D-VFR6.

120. See, e.g., H3 Podcast Highlights, YouTube's Copyright System Is Broken, YouTuBE (Oct. 27, 2018), https://perma.cc/HYS2-RCHV. 
creator wishes to use substantial amounts of another user's content under the belief that it is fair use, they would also take on the risk of a DMCA takedown or litigation. In theory, this should encourage minimal amounts of appropriation while allowing for a small fair use quotation carve out, ideally just enough for users to have the freedom to create and further the Constitution's goal of fostering creation. ${ }^{121}$ This proposal is not a fair use solution per se but rather a scheme built on upon the recognition that limited appropriation for fair use purposes actually facilitates further creation and value.

While some have proposed similar statutory compulsory licensing schemes to balance the interests of right holders and creators who use copyrighted works for fair use purposes online, ${ }^{122}$ the difficulties of passing legislation or advocating for judicial reform make most such proposals unattractive, particularly as such efforts can take years to implement, often getting bogged down in endless debate and proceedings. ${ }^{123}$ By leaving the burden on private entities like YouTube, these schemes can be implemented rapidly, without shaking up entire industries or unnecessarily involving industry players and parties with conflicting interests. Market-dominant entities like YouTube who implement such schemes can set the bar for the rest of the industry; as YouTube or another entity becomes increasingly attractive for more and more creators, other platforms may be incentivized to implement similar systems.

\section{B. Allowing Market Forces To Do the Work}

In addition to a fair use quotation licensing scheme, additional reforms might be found through the natural workings of the free market, as large right holders and user platforms change in response to public pressure and economic incentives. For instance, YouTube has demonstrated a receptiveness to the public concerns of its users and has made efforts to discourage the abuse of their copyright management tools. ${ }^{124}$ Still, the cynic might be skeptical that big-name right holders who control vast libraries of valuable copyrighted works have any real incentive to do anything but actively protect their properties against unauthorized use. Yet today, as Professor Tim Wu has suggested, there is a large category of pervasive, yet relatively harmless, uses of works that are technically infringing but are nevertheless widely permitted, perhaps due to "simple laziness or enforcement costs, a desire to create goodwill, or a calculation that the infringement creates an economic complement to the

121. See U.S. CONST. art. I, $\S 8, \mathrm{cl} .8$ (granting Congress the authority " $[\mathrm{t}] \mathrm{o}$ promote the Progress of Science and useful Arts, by securing for limited Times to Authors ... the exclusive Right to their respective Writings and Discoveries").

122. See, e.g., Conrad Postel, "Let's Play": YouTube and Twitch's Video Game Footage and a New Approach To Fair Use, 68 HASTINGS L.J. 1169 (2017).

123. See generally Andrew Rudalevig, Why Does Congress Have Such a Hard Time Passing Laws? Let's Blame the Constitution, WASH. POST (July 11, 2017), https://perma.cc/5PKU-RG29.

124. See Updates To Our Manual Content ID Claiming Policies, YouTube Off. Blog (Aug. 15, 2019), https://perma.cc/SC6Z-FN3E; YouTube Creators, How YouTube Fights Fraudulent Copyright Claims and Takedowns, YouTuBE (Mar. 26, 2019), https://perma.cc/QMG4-SLRF. 
copyrighted work - it actually benefits the owner."125 Referring to such uses - such as a fan creating a "loving website" for an obscure film - as "tolerated uses," Wu proposes the possibility that similarly infringing works can function as economic complements, thereby making the original works more valuable. ${ }^{126}$ Right holders who recognize the benefits of such a relationship may be incentivized to further permit such tolerated or fair uses.

Such a shift has already occurred in the video game streaming sphere. Many game studios, in the wake of booming demand for Let's Play videos on YouTube and Twitch, have revised their policies concerning the use of their properties to create videos. ${ }^{127}$ Whereas previously some studios like Nintendo greatly limited or directly opposed the efforts of content creators who used their games to produce Let's Play videos, the same studios have since loosened restrictions to permit, and even encourage, streamers and creators to more-or-less freely produce content and even monetize their videos. ${ }^{128}$ The advantages of doing so are obvious: free advertisement and increased publicity. Many large studios, such as Blizzard Entertainment and Epic Games, now permit users to create and monetize "fan content" like Let's Play videos or livestream videos, within the limitations laid out in their terms of use. ${ }^{129}$

Large right holders are not completely immune to changes in the market. As more consumers and YouTube creators appropriate copyrighted works for fair use or tolerated use purposes, right holders may alter their policies so as to actively encourage limited and creative use of their works. In the case of video game streaming, market forces seem to be turning in favor of more use. It may be unlikely that small right holders (such as, other independent YouTube creators) would respond in the same way as larger right holders would to similar market trends. Still, should the trend continue across other similar industries, YouTube may see more right holders opting not to issue DMCA takedowns on videos that resemble fair use.

\section{The CASE ACT}

One final area of reform worth mentioning briefly is the set of changes that could be brought on by the Copyright Alternative in Small-Claims Enforcement Act ("CASE Act"), which is currently pending in the U.S. Senate. A small claims tribunal for copyright disputes has many advantages as a potential solution to deal with the DMCA abuse problem. The CASE Act was written to empower small copyright owners to better protect their copyrights by offering them a "cost-effective

125. Wu, supra note 6, at 619 (emphasis added).

126. Id. at 630 .

127. For a comprehensive definition and overview of Let's Play videos, see Patrick Klepek, Who Invented Let's Play Videos?, KOTAKU (May 6, 2016), https://kotaku.com/who-invented-lets-play-videos1702390484.

128. See Richard Lawler, Nintendo Ends 'Creators' Program that Restricted Video Sharing, ENGADGET (Nov. 28, 2018), https://perma.cc/QY8M-62T2.

129. See Blizzard Video Policy, BLIZZARD EnT., https://perma.cc/LP43-LJXL (last visited Sept. 25, 2020); Fan Content Policy, EPIC GAMES, https://perma.cc/9NCC-NH6T (last visited Nov. 5, 2020). 
alternative" to federal court. ${ }^{130}$ Its streamlined process-involving specialized officers, telecommunicated proceedings, and relaxed and expedited discovery-is meant to permit the Copyright Claims Board ("CCB") to process a large number of claims in a relatively short time. ${ }^{131}$ Furthermore, the CASE Act would enable the $\mathrm{CCB}$ to hear claims arising out of misrepresentation under $\S 512(\mathrm{f})$ of the DMCA. ${ }^{132}$ Given the relatively small costs of pursuing a claim through the CASE Act, this might actually prove to mitigate the DMCA abuse problem, as content creators would have the opportunity to pursue misrepresentation claims or otherwise properly assert a fair use defense in litigation.

The CASE Act could essentially open the doors of recourse to YouTube users, like Shookbang, who previously had few options to fight infringement allegations. That being said, litigation - even streamlined and relatively cheap - is still a stressful and time-consuming affair. Whether small YouTube users would ultimately turn to a copyright small claims tribunal rather than capitulate to a DMCA takedown is open for speculation. Still, it is not unreasonable to hope that the CASE Act would work to discourage right holders from issuing bad faith DMCA takedowns on YouTube in the first place out of fear that the allegedly infringing users would readily file § 512(f) misrepresentation claims against them.

\section{CONCLUSION}

Congress recognized the need for a swift removal mechanism to curb infringing behavior in the digital age when it created the DMCA takedown mechanism. Today, billions of individuals across the world have the ability to copy, distribute, and perform copyrighted works just by virtue of having access to internet. Yet the ease and rapidity with which a right holder can effectuate a DMCA takedown brings the mechanism into tension with fair use. This much has been clear to the YouTube community for some time, as the DMCA takedown mechanism has been both an effective enforcement tool and a copyright boogeyman. In particular, the difficulties of evaluating fair use, demonstrating bad faith, and excessive litigation costs effectively make a proper fair use defense all but inaccessible to most YouTube creators.

As the largest video-hosting platform in the world, YouTube has a responsibility to its users to properly enforce their copyrights. However, this cannot come at the cost of stifling fair use and chilling creative behavior. YouTube is a massive creative hub, and in order to remain so, YouTube must do more to shield fair use from bad faith takedowns. The proposal contained herein - a fair use quotation licensing scheme - is just one of the solutions YouTube can implement to curb DMCA

130. Copyright Small Claims, COPYRIGHT ALL., https://perma.cc/5VG3-RJ2W (last visited Sept. 25, 2020)

131. See CASE Act of 2019, S. 1273, 116th Cong. (2019).

132. Id. § 1504 (2019) ("A claim under section 512(f) for misrepresentation in connection with a notification of claimed infringement or a counter notification seeking to replace removed or disabled material, except that any remedies relating to such a claim in a proceeding before the Copyright Claims Board shall be limited to those available under this chapter."). 
takedown abuse. As a large private actor, YouTube can take unilateral action to effectively balance these two interests without getting bogged down in the fight to enact large-scale copyright reform. Even acting alone, YouTube would impact billions of internet users with changes to its own copyright policies. This is no small burden, to be sure, but it is arguably a responsibility that comes with being an industry leader. In the absence of imminent copyright reform, it may increasingly fall on private entities like YouTube to be the ones to safeguard fair use in the digital age. 